\title{
Student Centered Approach to Teaching: What Does It Mean for the Stakeholders of a Community School in Karachi, Pakistan?
}

\author{
Sadruddin Bahadur Qutoshi ${ }^{\mathrm{a}, *}$ and Tikaram Poudel ${ }^{\mathrm{b}}$ \\ ${ }^{a}$ Karakorum International University, Gilgit, Pakistan \\ ${ }^{b}$ School of Education, Kathmandu University, Lalitpur, Nepal
}

\begin{abstract}
Assuming the effectiveness of student-centered approach to teaching, this study explores the perceptions of purposefully selected seven students and teachers from a community school in Karachi about this pedagogical approach. Using interviews and observations of classroom practices as methodological tools, we concentrate on finding answers to the questions: How does student-centered approach to teaching used in community schools in Pakistan contribute to achieving quality education? How does this approach affect teaching and learning activities? How does this approach facilitate teachers to overcome the problems of teaching and learning? The findings of this study identify that student-centered approach to teaching encourages students' engagement in teaching-learning activities focusing on individual interaction to achieve common objectives. However, inadequate resources, small sized classrooms, and lack of expertise on the part of teachers were the challenges to the teaching learning activities in the community schools. These findings would be valuable to teaching and learning communities and educational policy makers as well.
\end{abstract}

Keywords: Student centered approach, community school, quality education, teaching and learning

\section{Introduction}

This paper evaluates the perceptions and practices of student centered approach to teaching as a means to providing quality education in the context of the Ismaili Community Schools in Karachi, Pakistan, by using Weimer (2002) Model of Learner Centered Teaching as a conceptual framework. Many studies on learner centered teaching show that it is a process that engages learners and creates an environment of cooperation among peers to behave in a socially conscious manner to focus on group performance rather than individual performance (UNICEF, 2000). To achieve this group performance, learners can seek help of peers in group and teachers on the site for "guidance, wise counsel, critique and encouragement" (Weimer, 2002, p. 20) and collaboration. Therefore, the role of a learner 
becomes more responsible to be a partner in learning that is a paradigm shift, which is missing in teacher centered approach where students remain passive learners (Cheong, 2010; O’Neill \& McMahon, 2005).

Helping learners during the activities in cooperative and active learning situations (Tsay $\&$ Barady, 2010), teachers use different tools of assessment for learning by providing constructive feedback to improve learning. That is why, Student Centered Approach to Teaching (SCAT) is considered to be one of the best ways to achieve the objective of providing quality education to community children in community school system where children are mostly socially conscious about the importance of social interactions and team work in their daily life activities, out of their classroom, in their community life. In this way, they get constructive feedback to improve their skills of social interactions (McCombs, 1997). However, most of the teachers lag behind in using these strategies to achieve this objective for many reasons in the context of community schools in Pakistan. Therefore, teachers mostly prefer 'conventional methods' to complete their syllabi in the given period of time and provide just guidelines to the whole class to do things accordingly (Peterson, 2009). This teacher centered instruction again compels students to go for rote memorization to pass the high stake testing rather than getting enough chances to work in smaller groups, focusing on their learning difficulties and discussing with their peers and teachers for their 'powerful learning' (Hopkins, 2001; 2007; Kumandas \& Kutlo, 2010). In such a critical situation, the slogan of providing quality education through SCAT remains superficial and thus students become puppets, not intellectual and socially conscious citizens as depicted in the vision of Community Schools (CS).

The notion of developing CS was to provide quality education to the children of low income families at affordable fees within the community structure by mobilizing and utilizing required resources, increasing community participation, and adding institutional facilitation at different levels. As the concept of 'community schools was to develop, organize and manage within the community effectively to achieve the objective of providing quality education, School Managing Committees (SMCs) under the Community Based Education Societies were formed and registered under the Society's Act of Pakistan (Rugh \& Bossert, 1998). The structure of SMCs consists of chairman, member finance, honorary secretary (head-teacher), and 10 to 12 other members including two to three parent representatives whose children are studying in these community schools. The key stakeholders of the CS are students, parents, teachers, SMC members and community at large who altogether are responsible for improving the teaching learning conditions at schools. The concept of quality education as defined by the community, linked with Weimer' Model as framework of the study, was used to look into the practices and perceptions of teachers to what extent this concept is reflected in their practices in the school system. 


\section{Student Centered Approach to Teaching}

Student centered approach to teaching is conceived as an 'instructional philosophy' and modern pedagogical approach, which is opposite to teacher centered approach, i.e. the 'conventional teaching methodology' in which the teacher remains at the centre of instruction (Burnard, 1999; O’Neill \& McMahon, 2005) in the teaching learning process. Dewey (1938) asserts that traditional way of teaching has the limitation to focus on active learning and explains that "...there is no defect in traditional education greater than its failure to secure the active co-operation of the pupil in construction of the purposes involved in his studying" ( $\mathrm{p}$. 67). However, teaching focused theories like Bloom's Taxonomy (1954), experiential learning of Kolb (1984) based on John Dewey's, Kurt Lewin's and Jean Piaget's concepts of learning and flexible approach to teaching revealed that student centered approach to teaching is a paradigm shift from teacher to learner-centered, a deliberative effort to facilitate learner to achieve learning objectives by creating conducive learning environment using a variety of activities like activity based teaching with effective interactive relations between learners and teachers (Gredler, 2009; Johnson \& Johnson, 1998). In light of the perceptions of quality education, it is like 'one size does not fit all' paradigm because of its transition and dynamic nature. Its definition changes from person to person, community to community and country to country from time to time and who defines it under specific circumstances depending upon the influence of cultural, historical, local, national, international and global perspectives (Motala, 2000; UNICEF, 2000). However, the concepts of quality education to the community are: 1) children are given access to modern facilities like computer education according to their grade level; 2) individual attention is given to overcome learning difficulties through learner focused teaching; 3 ) teachers are given opportunities to learn through training, workshops, seminars, co-teaching with expert teachers to improve teaching learning practices; 4) providing students with opportunities to participate in local, regional and national level competitions to show their talents; 5) monitoring and evaluation of every teaching and learning activity is ensured through internal and external institutional support; 6) learning achievements are shared with parents, community and supporting institutions to encourage children to excel in curricular and co-curricular activities; 7) high achievers, competition winners and runners-up are appreciated in the community programs to boost their morale; 8) every event or activity is organized around learners' development and is well justified (Blumberg, n.d.). These perceptions of the school stakeholders are considered as quality standards.

\section{Theoretical Basis}

In the light of Weimer's Model of learner centered teaching, the quality standards in the community schools system discussed in the above section are evaluated through the exploration of perceptions, beliefs and practices of the teachers and students. According to this model, the five key premises are: 1) power shifts from teacher to a more egalitarian 
classroom - from teacher centered to student centered; 2) the use of content is just for students to think critically; 3) a shift in authoritarian role of teacher to facilitator; 4) return the responsibility for learning to the students; and 5) utilize assessment measures not just to assign grades, but to promote learning (Bilimoria \& Wheeler, 1995; Weimer, 2002).

The first key component of Weimer's Model, a paradigm shift from teacher centered to student centered, is the main indicator that teachers are using SCAT(O'Neill \& McMahon, 2005). In this approach, the role of teacher remains a helper, facilitator, mentor, 'formator' (Ang, Gonzalez, liwag, Santos, \& Vistro-Yu, 2001) and a guide whereas students' role remains central in the whole process as "active participants in learning and co-constructors of knowledge" (Meece, 2003, p. 111). This active participation of students creates enjoyment in their learning through exploration and construction of knowledge where the teacher encourages, mentors and engages them in critical thinking process to achieve the desired objectives of learning (Law, 2007). As a result of this relationship, an egalitarian classroom environment is created in such kind of practices. In this whole process of teaching and learning, if a child does not come up to the mark or to the set standard "the child is not dismissed as a failure; rather the teacher considers what can be done to enable this child to learn" (Law, 2007, p. 226) and this concept is somehow linked to the perceptions of providing quality education at the community schools. However, Simon (1999) argues that focusing every individual in such a way is not possible in practice. For example, in a limited time period if teachers will give more focus on slow learners that may result in ignoring fast learners. However, it is very difficult to experience such kind of power shift in cases of more experienced and senior teachers and it is also very difficult to say such practices necessarily reflect the essence of quality education if individuals are treated in such a way (Ang et al., 2001). So, it may be quality education for children with learning difficulties but it may only be the loss of time for others in the same class.

It is widely agreed that teaching is not something depositing into the minds of learners through teachers' control rather it is creating opportunities to individual learners to overcome learning difficulties by involving in learning situations with mainstream learners where they can come with their own creativity through exploration and interaction (Freire, 1970; Gredler, 2009). In this connection, SCAT is an interactive way to facilitate learners who have different ideas and views to share with each other in smaller group settings (Pantiz, 1996) to get insights of a topic under discussion. However, involving children with empowerment in their preferred activities can reinforce their participation in all activities because students are not motivated to learning every time. On the contrary, it is the teacher who creates conducive learning environment by selecting such preferred learning activities which can reinforce children to show their interests in the class.

In doing so, teachers have to interact friendly focusing on task to facilitate learning with appreciation for active participation to boost students' interest towards learning; and such 
kind of friendly interactive facilitation is considered as a way to provide quality education in community schools. According to Guthrie (2004), to create interest in learning, teachers use multiple ways to engage learners through a variety of activities like activity based teaching. Thus, the concept of SCAT is to focus on activity based teaching with a clear focus on improving the learning conditions of students who can take responsibility for their learning by working together in a group (Peklaj, 2006). Creating conditions for students to take part in activities with self responsibility develops confidence and improves achievement in their life chances (Piert, 2013). However, there does not exist a clear evidence to support the direct relationship between activity based teaching and development of self responsibility in learners. Moreover, SCAT is a paradigm shift in teaching methodologies in order to create a cooperative and collaborative learning environment in their classroom. One of the aims of paradigm shift was to minimize negative competition focusing more on getting high grades rather than on active learning (Johnson \& Johnson, 1998; Kumandas \& Kutlo, 2010).

Theoretically, the rationale for paradigm shift was to make students realize the value of success in group work by achieving common objectives rather than being in a race of competition among their classmates. Contrary to this, the concept of quality education in the community schools focuses on competitions and race among children to be the first among others. Therefore, it might be quality education for this school system but not for others. Moreover, SCAT in light of this model is a cooperative learning environment where teachers use the content as a source to help learners build on their prior knowledge to connect their ideas and discuss things in group, providing equal chances to express, apply to their context, analyze the situation, and create conceptual understanding of a topic under discussion (Cheong, 2010; Kagan, 1997; Piert, 2013). It helps students to learn by communicating their understanding, experiences and helping their peers to convince their views where teachers become co-learners in these interactive discussions with different talents, abilities, and background of learners to achieve their common objectives on task, rather than being first among others (Pantiz, 1996). However, it is not so simple for every novice teacher or even for some experienced teachers who have the fear of loss of power of authority or may not have the motivation to change their classroom as a platform for socialization for purposeful learning.

All the five key premises of Weimer's model in light of quality education as defined by the community schools can be reflected in the forms of "self regulated learning practices where students' motivation, confidence and interest for learning are all adversely affected when teacher controls the process through and by which they learn" (Weimer, 2002, p. 23). In such a situation where the teacher controls the whole process of teaching and learning, almost all decisions are taken by the teacher for learners. In addition to that, the content focused practice for any justification, i.e. to complete the syllabus, is also another indicator to teacher centered approach. Whereas in SCAT, a conducive learning climate is created and 
students are given multiple opportunities to take most of the decisions related to their learning and interest. An environment of trust and respect for each other, collegiality and cooperation for team learning and demonstration of high confidence and freedom for learning with 'autonomy and responsibility' is practiced in SCAT classes (Weimer, 2002, p. 102). In such a situation, students can seek support, guidance and feedback whenever required and the role of the teacher remains a friendly facilitator, not a decision maker. This key concept of the model is used to evaluate the student centered approach to teaching through an exploration of teaching learning practices in the context of this study.

\section{Methodology}

In this empirical research, we are interested in a 'holistic in-depth investigation' (Zainal, 2007, p. 1) to explore stakeholders' views and practices on student-centered approach to teaching including factors affecting this approach to teaching, challenges and alternative strategies to cope with these challenges within the context of a community school in Karachi, Pakistan.

As Saunders, Lewis, and Thornhill (2000, p. 92) talk about the importance and use of appropriate research strategy for data collection and analysis "...what matters is not the label that is attached to a particular strategy, but whether it is appropriate for your particular research..." that links with the research questions to explore, we used case study. Case study research methodology is "an empirical inquiry that investigates a contemporary phenomenon within its real-life context in which multiple sources of evidence are used" (Yin, 1994, p. 23) and this characteristic of the case study research enhances data credibility (Patton, 1990; Yin, 2009). In this particular context, among many other strategies, case study is the most appropriate strategy for an in-depth study of a phenomenon, to make meaning of what people say and do in a real situation. In order to collect the required and reliable data, we used semistructured interviews and classroom observation. Then we went through the process of triangulation (Denzin \& Lincoln, 1994) that provided a reliable basis for data analysis and interpretation.

We believe that the processes of data collection and analysis need to be carried out at the same time. According to Yin (2009), "...pattern matching, linking data to propositions, explanation building, time-series analysis, logic models, and cross-case synthesis" (p. 26) are five techniques of data analysis depending upon the type of case study. On the other hand, 'categorical aggregation and direct interpretation' are classified as types of analysis as per Stake (1995). However, to reach the interpretation through thematic analysis, the following three important principles of analysis: "use of all of the relevant evidence; exploration of major rival interpretations; and addressing significant aspects of case study" (Rowley, 2002, p. 9) were used in a systematic manner. 
Moreover, in the context of this study, as the literature review identifies some of the existing gaps in the practices and barriers to achieve the objectives of SCAT, the primary focus remained on group interviews of purposefully selected seven students ( 2 from grade III, and one each from grade IV-VIII) and seven teachers of the same classes to explore their perceptions and beliefs about this approach to teaching. To collect the data by using group interviews through probing technique, we encouraged the participants to provide information in whatever form they would like to share like facts, opinions, ideas, understanding, attitudes and intentions regarding SCAT in their classes.

To conduct Semi-structured Interviews (SSI), we developed an interview guideline that consisted of a list of open ended questions in a sequential order based on our subsidiary research questions. The purpose of this SSI guideline was to obtain 'reliable and comparable qualitative data' within a single phase of interview from the research participants (Bernard, 1988). To ensure that the main points were recorded in a proper way, a note-taker was used who noted the points shared by the participants during the interviews.

The required data were collected until we reached a saturation point during these interviews whereas data analysis, as a process of drawing meanings, and making sense of the meanings from the data was conducted in six different steps. This process of analysis involved: 1) reading the data for clarifications and corrections; 2) transforming all relevant data into meaningful discourse; 3 ) finding key themes that emerged out of the data; 4) arranging the themes in a proper order; 5) putting data pieces on index cards for sorting out; and 6) developing a list of final themes based on a processing matrix with reference to the key themes for every research question.

To obtain the pure meaning of a phenomenon or 'to get more accurate picture' of a situation within a 'social world', we also used classroom observation as another tool since multiple sources of data collection tools ensure triangulation (Saukko, 2003). The classroom observation checklist was prepared based on the data collected from the interview with the students and the teachers in order to check the similarities and differences out of the two sets of data for the purpose of analysis.

As the specific purpose of this paper was to address the key issues related to SCAT in a CS system in Karachi, Pakistan, this study was delimited to one school, as a unit of analysis. Thus, generalizability of findings will not be possible to a wider context. However, the findings can help schools in the developing world, especially those which have similar contexts to the community school system in Pakistan, to learn some interesting lessons to improve SCAT practices.

\section{Results and Discussion}

The results obtained from the analysis of the data are discussed as perceptions / beliefs of teachers about SCAT; challenges to use SCAT; alternative strategies to overcome the 
challenges; assessment of SCAT; and factors affecting SCAT in the community school followed by our commentary/conclusion.

\section{Perceptions / Beliefs of Teachers About Student Centered Approach to Teaching}

The classroom observations and views of teachers and students revealed that SCAT is an interactive technique to teaching which focuses on group work, cooperative and collaborative work, flexible learning, and activity based teaching to achieve learning objectives (Cheong, 2010; Peklaj, 2006). By using these strategies, teachers provide the learners with a variety of learning opportunities like service based learning, problem based learning and team-based learning. It was not identified from the data that teachers are using team-based learning and problem based learning. However, students are exposed to a variety of learning situations such as smaller group works, cooperating and collaborating with each other inside the classroom and sometimes outside the classroom in the form of service based learning (Cheong, 2010). Moreover, "teachers observe learners in the classroom activities to see how they interact with each other and try to identify the level of their participation and understanding. They put questions to check their understanding and provide immediate feedback accordingly" (Interview, October 9, 2012). This is exactly what the concept of quality education is that community schools define for teaching and learning conditions in these school systems. However, the changing roles of teacher as supporter, formator, facilitator, co-learner and observer need to be reflected in terms of the quality of support provided to individuals that is required during small group discussions (UNICEF, 2000). On the other hand, it is equally important to see the level of discussions, interactions and equal participation among the group members and their understanding to ensure individual focused learning.

Some other views identified during the focused group interviews with students included that "...some teachers are strict and they tell us to finish the work soon. Teachers sometimes go out of class or sit on a chair. We try to finish work quickly but some colleagues do not help in group" (Interview, October 9, 2012). Furthermore, students expressed their views about the teachers who remain on task with students and provide their assistance while students are doing their group work. "Some teachers come to us and ask like a friend. We enjoy working together and share ideas with teachers. A teacher in particular sometimes laughs at the things we do wrong. But still she does not punish... but guides us how to do the task." This shows that teacher's friendly behavior drives learners to enjoy learning but harsh behavior, lack of interest to see how children learn, and absence of support to learners on task are more serious matters for the schools as a system. Such kind of practices, although a few cases, do not support the claims of providing quality education at these institutions rather hamper the efforts to provide quality education to community children. Identifying the behavioral issues related to teachers will help the school administration to bring positive 
changes in practices in future alongside encouraging teachers to work on problem based learning and team based learning in their classes.

\section{Challenges to Use Student Centered Approach to Teaching}

Views of students, teachers and our observations show that there are numerous challenges on the way to implementing SCAT in community schools. These are lack of time on tasks, 40 minutes periods for all subjects, smaller rooms with fixed furniture, fully packed classes with students, less access to computer lab and misuse of classroom resources due to sharing of school building, less experienced and new teachers, and lack of support from school administration to take initiatives, etc. In such a complex situation, only a few teachers who are highly skillful and have expertise can handle SCAT in their classes but majority of teachers blame poor resources and insufficient support as challenges. This kind of situation offers teachers a chance and justification to switch to teacher centered teaching mode. Ultimately, the learners have to suffer badly and cannot get the education that has been claimed by the school stakeholders in their vision. This finding validates the finding of Lea, Stephenson, and Troy (2003) and O’Neill and McMahon, i.e. "many institutions or educators claim to be putting student-centered learning into practice, but in reality they are not" (2003, p. 322).

Using interactive, smaller group discussion and 'flexible teaching' as a teaching strategy in classes with a huge number of students within a short period of time, both teachers and students found the learning process very tedious and they did not enjoy teaching and learning in most of the cases. Teachers expressed their concerns about the shortage of time, space and other resources. "... we try to use these methods in 40 minutes period with more than 40 students in small sized classes with few teaching aids; that is not fair...sometimes, we just teach the topics to the whole class and cannot focus on individual learning" (Interview, October 9, 2012). Time, space and resources are very important factors in SCAT along with teachers' knowledge, skills and expertise and these all factors are interconnected and have a huge impact on learners (O’Neill \& McMahon, 2005). However, working with such limited resources is a challenging and exasperating situation rather than enjoying the teaching and learning. In such a situation, the community quality education standards do not match with the evidence of actual practices. This huge gap between ground realities and the claims of the provision of quality education to community school children puts a big question mark to the policy makers and all stakeholders.

In addition to lack of resources, another problem in community schools was found to be misuse of the classroom resources (O’Neill \& McMahon, 2005). The sharing of school building with religious education centre, operating in the evening shift, etc. were found to be the main causes of resource dependency and misuse.

\section{Alternative Strategies to Overcome the Challenges}


It was very interesting to know that teachers of the community schools have alternative solutions to some of the challenges that they face during their teaching and learning practices. In the context of formal classroom setup, scarcities of time, space and resources remain redoubtable problems in order to meet the objectives of student centered approach to teaching. To overcome these problems, teachers design their lessons and incorporate some activities for outside classroom learning. They guide learners briefly in the class and send them in groups to complete their tasks and come with their learning outcome in the next class for presentation. Teachers expressed their views that,

...we use collaborative learning strategies; sometimes, we send them out of class for activities that take more time... we send learners in groups with a checklist of what to do and what to achieve. They sometimes come with extra ordinary results that we cannot expect of them. But their presentations show that they do these things very interestingly.

This is what we can do for our students but it needs more creative planning with a lot of care. (Interview, October 9, 2012)

It is very exciting to know the creative engagement of learners in out-of-classroom activities for learning. However, such kinds of efforts need commitment of teachers with innovative ideas and expertise. Moreover, it is a very much challenging task for less experienced and novice teachers to plan activities and to engage learners in such a constructive way. On the other hand, it can be argued that providing group learning assignments without teachers' involvement in terms of support on task and monitoring their work in groups, the notion of collaborative learning does not guarantee activity based learning. It is very difficult to identify how many group members actively and collaboratively work to achieve learning objectives without guidance and monitoring of teachers outside the classroom (Cooper, Robinson, \& McKinney, 1993; Shimazoe \& Aldrich, 2010). Moreover, it needs an evidence based assessment that could provide enough proof of their learning in such kinds of activities outside their classes. This implies that teachers of the community schools will have to think about these practices.

\section{Assessment of Student Centered Approach to Teaching}

The perspectives of teachers regarding assessment of learning, both for graded and non graded group activities either inside the classroom or outside the classroom, appeared encouraging in a way they are aware of the importance of assessment not only for grading purpose but also for improving learning (Gibbs \& Simpson, 2004). Teachers said that "... we use the assessment for learning... it is just for the purpose of knowing to what extent students have learnt ... it is not for grading them for the group task". However, students' views were found somehow different when they said "...teachers, most of the time, assign graded tasks and we have to show results at any cost... but they help during activities and ask questions... we really enjoy giving answers to non-graded activities." This shows that although teachers 
use formative assessment for learning, their focus still remains on assessment for grading purposes. It is argued that just asking questions and providing assignments for learning do not necessarily reflect the real essence of assessment for learning. Teachers need to focus on sharing and communicating the assessment criteria with learners as well as their expectations about their learning. Moreover, respecting diverse talents and ways of learners during assessment process enables learners to think in a positive way to improve more. In addition to providing general feedback on task, latest tools for assessment like Immediate Feedback Assessment Technique (IFAT) should be used to enable learners to think critically to find right responses according to the need of the situations.

\section{Factors Affecting Student Centered Approach to Teaching}

Findings revealed that there are many factors that affect the whole process of teaching and learning at the community schools. However, the above mentioned challenges no doubt badly affect both the teachers and students to foster a socially accommodative learning environment in construction of experiences. To enable learners to construct new knowledge through experiences heavily depends upon the knowledge, skills and attitude of teachers (Dewey, 1938). It was identified that most of the teachers are inducted having no pre-service training or experience of teaching and thus cannot handle SCAT classrooms. And during classroom activities, in such a situation, learners most of the time get clear through asking questions to the teachers about what to do. In such a confusing situation, students become irritated and working in groups becomes just a loss of time and resources. Students said that “... in the classes of some teachers, we do not enjoy activities...we do not understand exactly what to do." Properly planned activities can help students to get engaged in their learning and can motivate them towards learning. On the other hand, teachers claimed to face some difficulties in making activities more live and interesting for learners just because of unavailability of required resources in time. They said that,

...we have lack of teaching learning resources... we have to request the accountant with a strong justification to get some extra charts, colors, markers, papers, glue, etc. to make our group learning activities engaging and interactive by providing everything that students require during their task. Sometimes, we do not get those required materials and we have to rely on the alternatives that learners do not enjoy. (Interview, 9 October, 2012)

Another hindering factor identified was what teachers called 'strict rules of the school administration'. They cannot bring changes in the formal structured way to teaching and learning. They said,

...sometimes we got good ideas to do something new for our learners ... coming out of the routine activities ... for example, we want to take our students out of class and just let the learners observe physically the plants in the community park and find what things are 
required for a plant to live and grow healthy, etc...to do this, head-teachers' support and permission is very important and without that we cannot take such initiatives. (Interview, 9 October, 2012)

Based on the findings, it is asserted that providing required resources and encouraging teachers coming with initiatives and hiring teachers with relevant experience and skills can make the environment more conducive for learning to experience. However, some strict rules of the school, limited and misuse of resources, and fresh graduates' induction policies may hinder the way to provide opportunities for learning through creativity and innovations.

\section{Discussion and Conclusions}

Perceptions of teachers and students and our observations of classroom practices revealed that SCAT is a challenging job for the teachers but it gives interesting learning experiences for the students if activities are well planned and executed with great care and skills in a collaborative manner. However, teachers with commitment, innovations, expertise and experience can make alternative ways to achieve the learning outcomes effectively through inside and outside classroom activities if resources and support with appreciation and rewards from school administration are provided timely. The findings clearly revealed that only a few teachers are designing outdoor (outside classroom) activities to engage learners in self directed independent learning. Some of the community school teachers purposefully design independent learning opportunities for their students to enhance creativity and sense of responsibility. These unique alternative strategies for independent learning are used to achieve the objectives of SCAT which they cannot achieve in a formal classroom setting due to lack of administrative support and scarcity of required resources including shortage of time. The alternative strategies used by those few teachers within a complex situation due to multiple challenges seem to be innovative ways to achieve SCAT in the context of community schools, which is no doubt a contribution to the theory of learner centered teaching.

However, in the presence of administrative support, SCAT can be used for creating learning focused engagements successfully in terms of facilitation to smaller group works through discussions, sharing, thinking, exploring, analyzing, and interpreting meaning of the concepts in a cooperative and collaborative environment supported and assessed by a class teacher (Cheong, 2010). And provision of such support and facilitation with required resources can enable even novice teachers to use SCAT in the community schools.

However, it would be more encouraging if teachers go a step forward to create teams (even one team on a three seater desk due to fixed furniture in class) rather than groups for 'team learning' and 'problem based learning'. Moreover, in SCAT, learners enjoy learning, feel proud of being partners in learning with teachers, participate actively, and take 
responsibility for their own learning provided that the required amount of facilities are made available and a friendly learning environment is created.

At the same time, it is challenging for teachers in the context of community schools where teachers face not only the fear of loss of power but also scarcity of resources, time and space to conduct group works, problem based learning activities and to enhance critical thinking activities in a conducive learning environment in their classes. These kinds of challenges for teachers in community schools confine them to operate within all the five key premises of Weimer's model of student centered approach to teaching that has been taken to analyze the claims of community to provide quality education through SCAT.

On the other hand, to overcome some of these challenges, school management needs to focus on the effective use of available resources, providing required resources, arranging training and support for new and less experienced teachers, and encouraging innovative ways to learning through doing. These were found to be some contextual solutions to the existing problems in the community schools. Based on the findings, it is concluded that student centered approach to teaching is one of the best ways to enable a learner to become a lifelong independent learner who can take responsibility for his or her own learning.

\section{References}

Ang, R. P., Gonzalez, M. C. T., Liwag, M. E. C., Santos, B., \& Vistro-Yu, C. (2001).

Elements of student centered learning. Quezon City, Philippines: Ateneo de Manila University Loyola Schools.

Bernard, H. Russell. (1988). Research methods in cultural anthropology. Newbury Park,

California: Sage.

Bilimoria, D., \& Wheeler, J. V. (1995). Learning-centered education: A guide to resources and implementation. Journal of Management Education, 29(3), 402-428.

Bloom, B. S. (1954). Taxonomy of educational objectives. New York: Longman's Green and Company.

Blumberg, P. (n.d.). Implementing learning centered approach in your teaching.

Philadelphia: University of the Sciences in Philadelphia.

Cheong, C. (2010). From group-based learning to cooperative learning: A metacognitive approach to project-based group supervision. Informing Science: The International Journal of an Emerging Transdiscipline, 13, 84.

Cooper, J., Robinson, P., \& McKinney, M. (1993). Cooperative learning in the classroom. San Francisco: Jossey-Bass.

Denzin, N. K., \& Lincoln, Y. S. (Eds.). (1994). Handbook of qualitative research. Thousand Oaks, CA: Sage.

Dewey, J. (1938). Experience and education. New York, NY: Macmillan.

Freire, P. (1970). Pedagogy of the oppressed. New York, NY: Continuum. 
Gibbs, G., \& Simpson, C. (2004). Conditions under which assessment supports students' learning? Learning and Teaching in Higher Education, 1, 3-31.

Gredler, M. (2009). Learning and instruction theory into practice. New Jersey, NJ: Pearson.

Guthrie, J. T. (2004). Classroom contexts for engaged reading: An overview. In J. T. Guthrie, A. Wigfield, \& K. C. Perencevich (Eds.), Motivating reading comprehension: Conceptoriented reading instruction (pp. 1-24). Mahwah, NJ: Lawrence Erlbaum.

Hopkins, D. (2001). School improvement for real. London: Routledge/Falmer,

Hopkins, D. (2007). Every school a great school. Berkshire, England: Open University Press/McGraw Hill.

Johnson, D. W., \& Johnson, R. T. (1989). Cooperation and competition: Theory and research. Edina, MN: Interaction Book Company.

Kagan, S. (1997). Cooperative learning. San Juan Capistrano, CA: Kagan Cooperative Learning.

Kolb, D. A. (1984). Experiential learning: Experience as the source of learning and development. New Jersey, NJ: Prentice-Hall.

Kumandas, H., \& Kutlu, O. (2010). High stakes testing: Does secondary education examination involve any risks? Procedia Social and Behavioral Sciences, 9, 758-764.

Lea, S. J., Stephenson, D., \& Troy, J. (2003). Higher education students' attitudes to student centered learning: Beyond 'educational bulimia'. Studies in Higher Education, 28(3), 321-334.

Law, W. K. (2007). Frontiers for learner-centered IS education. Journal of Information Systems Education, 18(3), 313-320.

McCombs, B. \& Whistler, J. (1997). The learner-centered classroom and school: Strategies for increasing student motivation and achievement. San Francisco, CA: Jossey-Bass.

Meece, J. L. (2003). Applying learner-centered principles to middle school education. Theory into Practice, 42(2), 109-116.

Motala, S. (2000, March). Education transformation and quality: The South African experience. Paper presented at the Annual Meeting of the Comparative and International Education Society, San Antonio, Texas.

O’Neill, G., \& McMahon, T. (2005). Student-centered learning: What does it mean for students and lecturers? University College Dublin: AISHE.

Panitz, T. (1996).Getting students ready for learning. Cooperative Learning and College Teaching, 6(2), 10-30.

Patton, M. (1990). Qualitative evaluation and research methods (2nd ed.). Newbury Park, CA: Sage.

Peklaj, C. (2006). Cooperative activity and its potential for learning in tertiary education. Horizons of Psychology, 15(3), 37-50.

Peterson, T, H. (2009). Engaged scholarship: Reflections and research on the pedagogy of social change. Teaching in Higher Education, 14(5), 541- 552. 
Piert, J. H. (2013). Thirty years in the storm: Leadership at an African-centered school. The Urban Review, 45(3), 376-394.

Rowley, J. (2002). Using case studies in research. Paper presented to School of Management and Social Sciences, Edge Hill College of Higher Education, Ormskirk, Lancashire, England.

Saukko, P. (2003). Doing research in cultural studies. An introduction to classical and new methodological approaches. London: Sage.

Saunders, M., Lewis, P., \& Thornhill, A. (2000). Research methods for business students (2nd ed.). Harlow: Pearson Education.

Shimazoe, J., \& Aldrich, H. (2010). Group work can be gratifying: Understanding and overcoming resistance to cooperative learning. College Teaching, 58, 52-57.

Simon, B. (1999). Why no pedagogy in England? In J. Leach \& B. Moon (Eds.), Learners and pedagogy (pp. 34-45). London: Sage.

Stake, R. E. (1995). The art of case study research: Perspective in practice. London: Sage.

Tsay, M., \& Barady, M. (2010). A case study of cooperative learning and communication pedagogy: Does working in teams make a difference? Journal of the Scholarship of Teaching and Learning, 10(2), 78- 89.

UNICEF. (2000). Defining quality in education. Paper presented at the meeting of the International Working Group on Education, Florence, Italy.

Weimer, M. (2002). Learner-centered teaching: Five key changes to practice. San Francisco, CA: Jossey-Bass.

Yin, R. K. (1994). Case study research: Design and methods. Newbury Park, CA: Sage.

Yin, R. K. (2009). Case study research design and methods: Applied social research method series (4th ed.). Thousand Oaks, CA: Sage.

Zainal, Z. (2007). Case study as a research method. Jurnal Kemanusiaan, 9, 1-6. 